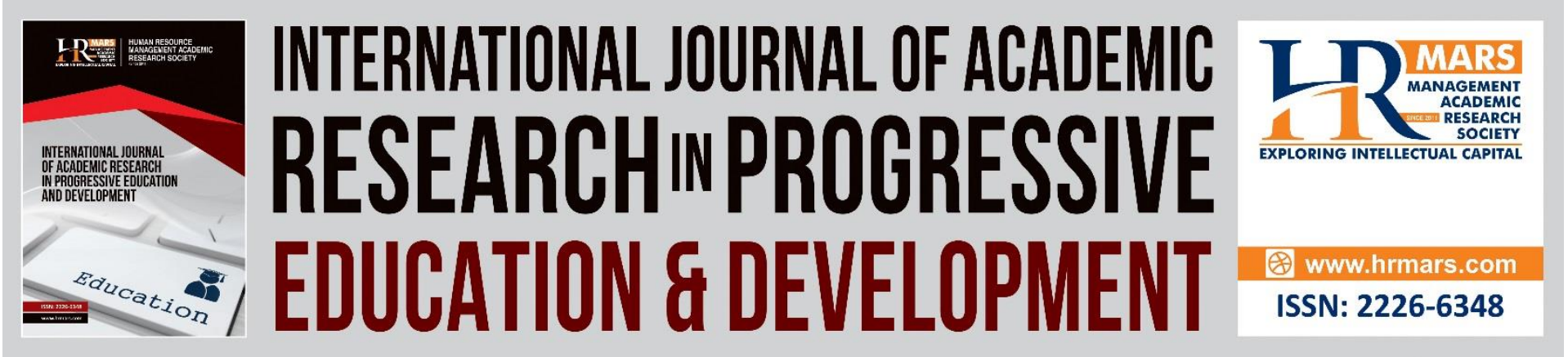

\title{
Determinant Factors in Selecting University: Evidence from Secondary School Students in Sarawak
}

Pick-Soon Ling, Lucy Chuo Mee Hong, Lau Siew Yun

To Link this Article: http://dx.doi.org/10.6007/IJARPED/v10-i3/11018～DOI:10.6007/IJARPED/v10-i3/11018

Received: 05 July 2021, Revised: 15 August 2021, Accepted: 29 August 2021

Published Online: 22 September 2021

In-Text Citation: (Ling et al., 2021)

To Cite this Article: Ling, P.-S., Hong, L. C. M., \& Yun, L. S. (2021). Determinant Factors in Selecting University: Evidence from Secondary School Students in Sarawak. International Journal of Academic Research in Progressive Education and Development, 10(3), 1015-1030.

Copyright: (C) 2021 The Author(s)

Published by Human Resource Management Academic Research Society (www.hrmars.com)

This article is published under the Creative Commons Attribution (CC BY 4.0) license. Anyone may reproduce, distribute, translate and create derivative works of this article (for both commercial and non-commercial purposes), subject to full attribution to the original publication and authors. The full terms of this license may be seen at: http://creativecommons.org/licences/by/4.0/legalcode

Vol. 10(3) 2021, Pg. 1015 - 1030

http://hrmars.com/index.php/pages/detail/IJARPED

JOURNAL HOMEPAGE

Full Terms \& Conditions of access and use can be found at http://hrmars.com/index.php/pages/detail/publication-ethics 


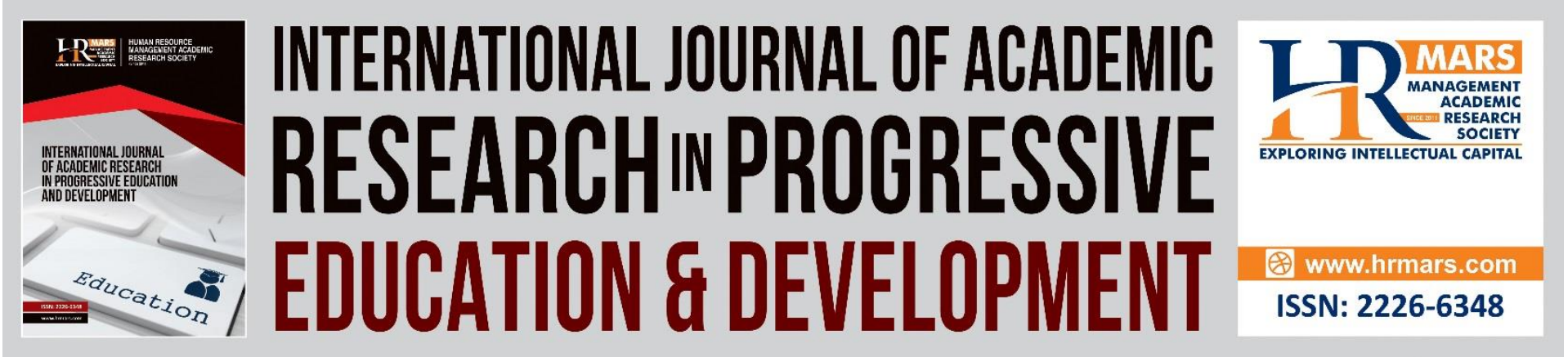

\title{
Determinant Factors in Selecting University: Evidence from Secondary School Students in Sarawak
}

\author{
Pick-Soon Ling \\ School of Business and Management, University College of Technology Sarawak, \\ 96000 Sibu, Sarawak, Malaysia \\ Email: ling.pick.soon@ucts.edu.my \\ Lucy Chuo Mee Hong \\ Sekolah Menengah Kebangsaan Lingga, 95000 Sri Aman, Sarawak, Malaysia. \\ Email: lucychuomeehong@gmail.com

\section{Lau Siew Yun} \\ School of Business and Management, University College of Technology Sarawak, \\ 96000 Sibu, Sarawak, Malaysia. \\ Email: bbm19070004@student.ucts.edu.my
}

\begin{abstract}
With the increasing competitiveness of the higher education industry in Malaysia, each higher education institution is competing to recruit more students or increasing the students' enrolment to sustain in the industry. However, the determinant factors that influence students' behavioural intention in selecting a university have to be identified to come out with a more effective marketing strategy. Therefore, this study aims to identify the determinant factors that have a significant influence on the students' university selection decisions. A total of 133 valid responses were collected from secondary school students in Sarawak and analysed using partial least squared structural equation modelling (PLS-SEM). The results revealed that infrastructure, placement opportunities and parental advice were significantly influenced the students' behavioural intention in selecting a university, while cost and peer influences have no significant relationship towards the students' selection decision. This study offers new evidence on the factors that influenced students' behavioural intention in selecting a university by focusing on the secondary school students in Sarawak. Besides that, this study also discusses the implications, limitations and suggestions for future study. Keywords: University Selection, Theory of Reasoned Action, Secondary School Students, Placement Opportunities, Partial Least Square Structural Equation Modelling
\end{abstract}




\section{Introduction}

With the increasing demand from the industrial sector on knowledgeable and skilled workforce, the demand on university graduates continues to increase too. This is because the educational qualifications could ensure the employment of the students and also the success and marketability of the students after they have graduated (Wong, 2019). In Malaysia, the number of higher education institutions (HEIs) increased after the higher education (HE) industry liberation to encourage the private organizations to establish more private HEls. This is crucial to accommodate the increasing number of students as the public HEls have limited spaces to absorb a large number of students. Besides that, the establishment of the private HEls was also inspired by the Malaysian government's goals to become an excellent education hub in the region. Therefore, the increasing number of HEls, no matter in private or public sectors, has increased the competitiveness of the HE industry as those HEls have to compete with each other to gain more students' enrollment, especially in attracting local and international students (Mahdzar et al., 2021). Students' enrollment is particularly important for private HEls as the number of students has a direct impact on their revenues because the study fees are the main source of revenue for those private HEls.

The increasing competitiveness of the HE industry requires the HEls to implement a competitive marketing strategy to attract the interest of the students (Mahdzar et al., 2021). As mentioned by Mishra, Yousaf and Amin (2021), HE has transformed in scope, competition and variety and it has become more commercialized. Thus, the concept of competitive advantage is appropriate in determining the success of the HEls. Each HEl has to demonstrate their strengths to attract the students' intention, as it is difficult to attract the students in such competitive markets (Agrey \& Lampadan, 2014). Moreover, those HEls have to understand the demand of the students as it is important for the HEls to meet the requirement of the students. Nowadays, the students have become more savvy customers as they request better value for the money and they become more selective in selecting HEls (Mahdzar et al., 2021). The traditional marketing strategy may not be pertinent for students' recruitment as the HE industry has been changed and has now become more customer orientated.

University selection is a continuing debate subject matter as the demand and requirement of the students keep changing over time. HEls have to understand the determining factors that could influence the students' university selection decision to align with the students' expectations. Empirically, numerous studies have been investigated the determining factors on the students' university selection. However, the comprehensive framework to examine the selection factors are not well-established or limited as different perspectives are available (Mishra, Yousaf \& Amin, 2021; Mitic \& Mojic, 2020). Moreover, the selection criteria of the university have become more extensive and complex (Wong, 2019), and the different cultures may also cause the selection factors of universities to differ in a different research context (Sim et al., 2021). Besides that, there are mixed findings in the literature regarding the factors of university selection. Therefore, this study asserts to examine the significant factors that influenced students' behavioural intention in their university selection decision. Unlike the previous study, this study utilized the Theory of Reasoned Action (TRA) to determine students' behavioural intention in selecting a university. Students' selection decision could be influenced by the factors that are related to the attitudinal and normative beliefs. Thus, the TRA model could be an appropriate model to examine students' behavioural intention in selecting the university. This is similar to 
Awadallah and Elgharbawy (2020) whereby the TRA also applied in evaluating students' major selection on accounting courses.

This study provides several differences from previous literature. First, as there is a limited study focused on university selection decision in a general manner, therefore, this study intends to examine the factor of university selection in a general manner with no limit to a public or private university. In addition, the Malaysian secondary school students, especially the Form four and Form five students are the potential students to enrol on the HEls in the next few years. Thus, this study concentrates on this group of students as they are the potential "customers" of those HEls. Besides that, this study focuses on the secondary students in Sarawak. Sarawak is the largest state in Malaysia and students may have insufficient information in university selection decision making as majority of the secondary schools are located in the rural areas. With these differences, this study believes could offer new findings from a different perspective and this could enrich the literature, especially from the developing market context and different research settings.

\section{Literature Review}

\section{Theory of Reasoned Action (TRA)}

The Theory of Reasoned Action (TRA) was adopted as the base theory in this study as the behavioural intention of students could be predicted by two predictors, namely attitude and subjective norms. TRA was introduced by Fishbein and Ajzen (1975) and they proposed that an individual's actions are determined by their behavioural intention and it could be predicted by their attitudes and also subjective norms. Attitude is defined as the feeling of an individual toward the achievement of an objective, while subjective norms are the perception of an individual towards the ability in achieving their objectives. Therefore, in this study, the determinant factors that influenced students' behavioural intention in selecting a university were categorized into attitudes and subjective norms. For instance, cost, infrastructure and placement opportunities were categorised into attitudes as these three factors could influence students' feelings when they are deciding on the university. Besides that, parental advice and peer influences were categorized as the factors under subjective norms as the opinions and advice from parents and peers could affect students' perception and thus it will influence their decision. The proposed research model that showed the five proposed factors with students' behavioural intention was illustrated in Figure 1. Besides that, the hypotheses development of these proposed factors were discussed after that. 


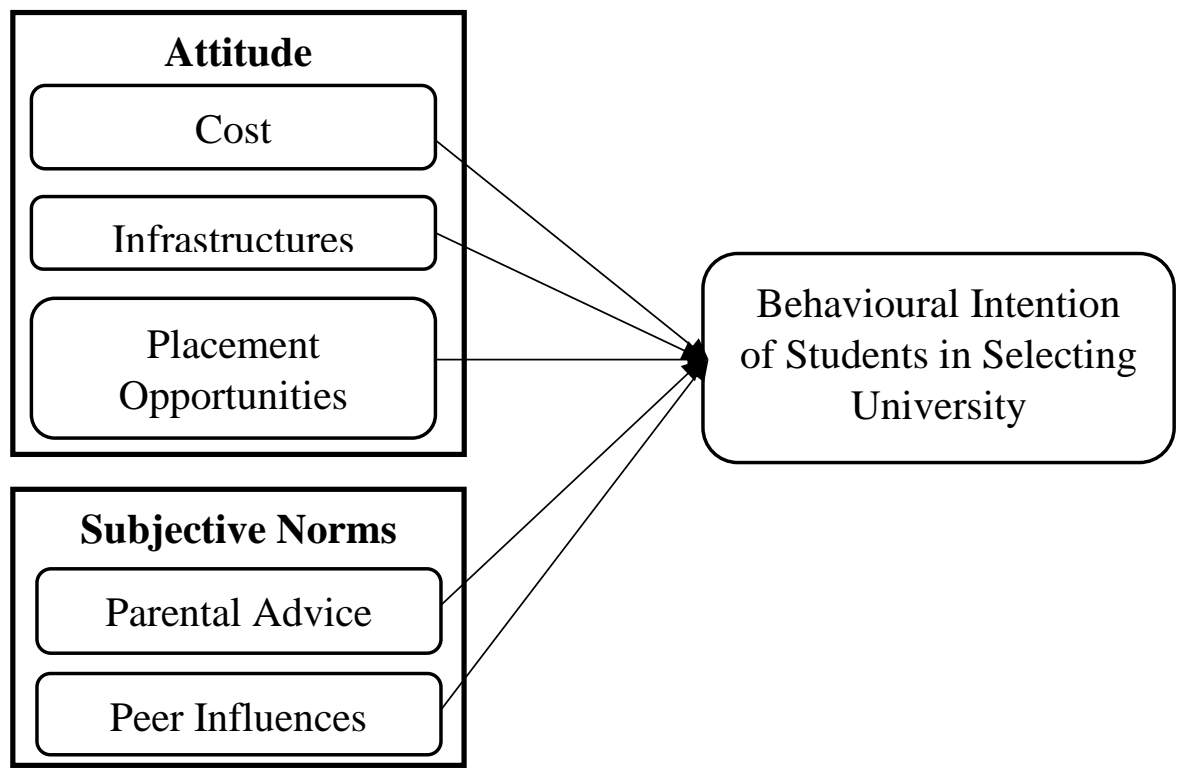

Figure 1: $\quad$ Proposed Research Model

\section{Cost}

Cost of study or study fees is the expenses that students or parents have to pay when they are enrolling in a university to study for their tertiary education, this includes tuition fees, registration fees, resources fees, accommodation fees, and the like. In Malaysia, the cost or study fees for public HEls is lower than the private HEls as the public HEls are subsidised by government. Therefore, students only have to pay a certain portion of the total fees as the remaining is supported by government. However, students have to pay much higher fees if they are enrolling with the private HEls as the fees from students are the main revenue sources for those private HEls. Theoretically, students or parents are likely to select a university that charges lower costs or study fees. Thus, the cost of the study is expected to significantly impact the students' behaviour intention in selecting a university. This proposition is supported by Mohd Yusuf, Ghazali \& Abdullah (2017), Mahdzar et al. (2021) and Nanath, Sajjad and Kaitheri (2021) as the cost of study or tuition fees was significant factor or most important factor that influenced university selection. However, the insignificant effects of cost or tuitions fees towards university selection are also found in Wong (2019). The impact of the cost of tuition fees required further investigation as previous studies found inconclusive results. Hence, the following hypothesis is proposed.

$\mathrm{H}_{1}$ : There is a negative significant relationship between the cost and students' behavioural intention in selecting a university.

\section{Infrastructure}

Infrastructure refers to the physical facilities or systems provided in a university as it is required for the daily operation of the university. The physical facilities including the classrooms, library and reading materials, accommodation, cafeteria, students' lounge, and others, while the systems of university include students' information systems, book borrowing systems, online-learning systems, students' evaluation systems and the like. All of these facilities and systems are important to provide a convenient learning environment for the students. For that reason, the infrastructure is expected to have a significant influence on the students' behavioural intention when they are selecting a university. Empirically, several 
studies have acknowledged the significant influence of the infrastructure on university selection. For instance, Mahdzar et al (2021); Ramalu, Abu Bakar, and Nijar (2013); Haron et al (2017); James-MacEachern and Yun (2017) suggested that the university tangibility such as campus facilities and educational facilities could influence students' university selection decision. Moreover, Mishra, Yousaf and Amin (2021) also suggested that infrastructure as one of the important factors that could affect the behavioural intention of students in selecting a university. Therefore, the hypothesis below was proposed.

$\mathrm{H}_{2}$ : There is a positive significant relationship between the infrastructure and students' behavioural intention in selecting a university.

\section{Placement Opportunities}

If a university could provide employment counselling services to the students who are going to graduate to help them to get suitable jobs, it could provide an advantage to the university. This is because the university is also concerned about students' wellbeing and life after graduation. Placement opportunities also referred to the connection of the university with the industrial organizations whereby students may be absorbed or recruited by the organizations after students have completed their study. Similarly, if the employment rate after graduation for a university is very high, it is likely to attract the interest of the potential students and also their parents as this could indicate that the university could produce graduates who are able to meet with the industrial requirements and therefore, it is easy for them to be recruited. For that reason, students' behavioural intentions in selecting a university are expected to be impacted by the placement opportunities. Several studies also remarked on the significant influence of placement opportunities on students' selection decisions. For example, Agrey and Lampadan (2014); Shah, Kansal and Chugh (2021) found that future graduate employment prospect is one of the evaluative criteria for universities students. Similarly, Songan et al. (2010) and James-MacEachern and Yun (2017) suggested that job opportunities or prospects after graduation is one of the important factors that influenced students' selection decisions. Mishra, Yousaf and Amin (2021) also proposed that placement opportunities as one of the factors that affected students' HEls selection. Thus, the following hypothesis was suggested.

$\mathrm{H}_{3}$ : There is a positive significant relationship between placement opportunities and students' behavioural intention in selecting a university.

\section{Parental Advice}

Parental advice is defined as the viewpoint, attitude or action from parents to their children regarding a particular matter. Usually, the students will seek advice or opinions from their parents when they don't know how to make a certain decision. With regards to university selection, the students, especially the secondary school students who don't have sufficient confident in selecting university, are likely to ask for advice from their parents. Parents are said to have a better understanding than their children and it could provide some useful advice to their children. Hence, parental advice is likely to influence the behavioural intention of the students in selecting a university. This is consistent with some prior studies such as Wong (2019); Yamamoto (2006); Alfattal (2017); Sarkodie, Asare and Asare (2020), who also found that parental advice or family influences have a significant impact on the students' university selection. Therefore, the hypothesis below was suggested. 
DEVELOPMENT

Vol. 10, No. 3, 2021, E-ISSN: 2226-6348 @ 2021 HRMARS

$\mathrm{H}_{4}$ : There is a positive significant relationship between parental advice and students' behavioural intention in selecting a university.

\section{Peer Influences}

Besides advice from their parents, students' behavioural intentions in university selection are also influenced by their peers or friends. The influence of their peer or friends on their attitudes, values and behaviours is also remarked. Students are likely to select the same university with their peers as they can accompany each other in the university as they need to adapt to the cultures and new environment of the university. The significant impact of peer influences on the students' university selection was also proven in prior studies. For instance, Wong (2019) suggested that peer has a strong influence on the students' university selection decision. Similarly, the same finding on peer's or friends' influence is also found in other studies (Yusuf, Ghazali \& Abdullah, 2017; Ahmad, Buchanan \& Ahmad, 2016; Wagner \& Fard, 2009). Therefore, the following hypothesis was proposed.

$\mathrm{H}_{5}$ : There is a positive significant relationship between peer influences and students' behavioural intention in selecting a university.

\section{Research Methodology}

The primary responses from the respective secondary school students in Sarawak were gathered by using the electronic questionnaire via a google form. To ensure the respondents are eligible for the study, purposive sampling was adopted and a total of 133 Form four and Form five students participated in this study. This sample size is sufficient for the proposed research model as it met the minimum sample size of 92 which is determined from the power analysis by using the rules of 0.15 effect size, 0.80 power level and five predictors. This sample size is also enough for a survey study as the ideal sample size for a survey study is 30 to 500 respondents as proposed by Roscoe (1975). For the measurement items in the survey, a total of 27 measurement items from the prior studies were adapted in this study such as cost, parental advice, peer influence and behavioural intention were adapted from Wong (2019), while placement opportunities and infrastructure was adapted from Mishra, Yousaf and Amini (2021). The respondents were asked to assess these measurement items using the fivepoint Likert scale to indicate their level of agreement on that particular item. The five-point Likert scale uses a range from one to five and represents strongly disagree to strongly agree. Besides that, five questions were also asked to understand the demographic characteristic of the respondents. To ensure the respondents were able to understand the contents of the questionnaire, the questionnaire was translated into Bahasa Malaysia version and both languages were used as this could reduce the confusions of the respondents. After the responses were collected, these data were analysed using the SmartPLS with the PLS-SEM approach. Moreover, the SmartPLS is also used to assess the construct and measurement items' validity and reliability.

\section{Results}

The demographic characteristic of the participated respondents was presented in Table 1. As showed in Table 1, 76 per cent of the respondents are female and only 24 per cent are male students. In terms of ethnicity, 53 per cent of the respondents are Chinese, followed by 26 percent Dayak students, and 15 per cent Malay students. Two-third of the respondents are students in Form Five and 34 per cent are Form Four students. Besides that, 69 students are 
studying under Science, Technology, Engineering and Mathematics package (STEM) and the remaining students are taking Arts and Humanities package. The respondents are mainly from four divisions in Sarawak which are Sibu (34.59\%), Kuching (20.30\%), Samarahan (20.30\%), Sri Aman (19.55\%) and the remaining are from other divisions.

Table 1: $\quad$ Demographic Profile of Respondents

\begin{tabular}{lll}
\hline Items & Frequency & Percentage \\
\hline Gender & & \\
Male & 32 & 24.06 \\
Female & 101 & 75.94 \\
Ethnicity & & \\
Malay & 20 & 15.04 \\
Chinese & 70 & 52.63 \\
Dayak & 35 & 26.32 \\
Other & 8 & 6.01 \\
Level of Study & & \\
Form 4 & 45 & 33.83 \\
Form 5 & 88 & 66.17 \\
Subject Package Option & & \\
Science, Technology, Engineering and Mathematics Package & 69 & 51.88 \\
Arts and Humanities Package & 64 & 48.12 \\
Division & & \\
Kuching & 27 & 20.30 \\
Samarahan & 27 & 20.30 \\
Sibu & 34.59 \\
Sri Aman & 46 & 19.55 \\
Other & 26 & 5.26 \\
\hline
\end{tabular}

The study continues with the multivariate normality test as it is important to determine the normality of the data to decide the appropriate analysis method. By using Mardia's coefficient analysis, the multivariate kurtosis coefficient is 69.8324 which is greater than the suggested value of 20 and this indicates that the dataset is not normal distributed (Byrne, 2013; Kline, 2011). Therefore, the PLS-SEM was the appropriate method to examine the relationship of the model. Besides that, the good-of-fit of the proposed model was also assessed using the Standardized Root Means Square Residual (SRMR) and the value of the proposed model is 0.0800 which is equal to the proposed threshold value $(0.08)$. Thus the model is considered good in fit (Hu \& Bentler, 1999). Moreover, the common method bias of the proposed model was also evaluated using Harman's single factor test and the result indicates that the total variance of the items explained in a single factor is 44.93 per cent and it's less than the suggested threshold of 50 per cent. So, the common method bias doesn't exist in the proposed model. 
Table 2: Model Measurement using Convergent Validity and Internal Reliability

\begin{tabular}{|c|c|c|c|c|c|}
\hline Factors & Items & Loading & AVE & CR & $\begin{array}{l}\text { Cronbach's } \\
\text { Alpha }\end{array}$ \\
\hline \multirow[t]{5}{*}{ Cost } & $\mathrm{C} 1$ & 0.8290 & 0.7190 & 0.9270 & 0.9020 \\
\hline & $\mathrm{C} 2$ & 0.8270 & & & \\
\hline & $\mathrm{C} 3$ & 0.8950 & & & \\
\hline & $\mathrm{C} 4$ & 0.8230 & & & \\
\hline & $\mathrm{C} 5$ & 0.8640 & & & \\
\hline \multirow[t]{5}{*}{ Infrastructure } & INF1 & 0.7920 & 0.6930 & 0.9190 & 0.8890 \\
\hline & INF2 & 0.8170 & & & \\
\hline & INF3 & 0.8650 & & & \\
\hline & INF4 & 0.8710 & & & \\
\hline & INF5 & 0.8140 & & & \\
\hline Placement & PO1 & 0.8040 & 0.6080 & 0.8610 & 0.7860 \\
\hline \multirow[t]{3}{*}{ Opportunities } & $\mathrm{PO} 2$ & 0.8490 & & & \\
\hline & PO3 & 0.7230 & & & \\
\hline & PO4 & 0.7370 & & & \\
\hline Parental & PA1 & 0.8230 & 0.7170 & 0.8840 & 0.8030 \\
\hline \multirow[t]{2}{*}{ Advices } & PA2 & 0.8260 & & & \\
\hline & PA3 & 0.8900 & & & \\
\hline Peer & PI1 & 0.7830 & 0.6350 & 0.8380 & 0.7370 \\
\hline \multirow[t]{2}{*}{ Influences } & $\mathrm{PI} 2$ & 0.8860 & & & \\
\hline & $\mathrm{PI3}$ & 0.7130 & & & \\
\hline Behavioural & $\mathrm{BI} 1$ & 0.9230 & 0.8240 & 0.9030 & 0.7870 \\
\hline Intention & $\mathrm{B} 12$ & 0.8910 & & & \\
\hline
\end{tabular}

Next, the model measurement was also assessed to ensure that the reliability and validity of the proposed model were achieved. The results of the convergent validity and internal reliability are provided in Table 2 . The outer loading of the remained measurement items was greater than 0.708 (Hair et al., 2017), except for one item for parental advice, two items for peer influences and two items for behavioural intention were deleted due to the lower loading value. The Average Variance Extracted (AVE) values for all factors is greater than the 0.50 threshold level (Hair et al., 2017). Therefore, both results indicated that the convergent validity was established in items and factors' levels. Besides that, both composite reliability (CR) and Cronbach's Alpha are employed to evaluate the internal reliability of each factor and the results showed that all factors have a higher value than 0.70 and this implied that the internal consistency was also achieved (Gefen, Straub \& Boudreau, 2000). Lastly, the discriminant validity of the factors was also assessed using the Hetero-Trait-Mono-Trait (HTMT) approach and the results are provided in Table 3. As shown in Table 3, all the factors' discriminant values are lower than the conservative level of 0.85 (Kline, 2011), except infrastructure and placement opportunities that are higher than 0.85 but still lower than 0.90 liberal value (Gold et al., 2001). Therefore, the discriminant validity is also established in the proposed model. 
Table 3:

Discriminant Validity using Heterorait-Monotrait (HTMT)

\begin{tabular}{lllllll}
\hline Factors & C & INF & PO & PA & PI & BI \\
\hline C & & & & & & \\
INF & 0.8210 & & & & & \\
PO & 0.7880 & $\mathbf{0 . 8 8 4 0}$ & & & & \\
PA & 0.6030 & 0.6250 & 0.6980 & & & \\
PI & 0.4350 & 0.5840 & 0.5680 & 0.6870 & & \\
BI & 0.5740 & 0.6550 & 0.7000 & 0.5580 & 0.3390 & \\
\hline
\end{tabular}

After the validity and reliability of the proposed model are established, the study continues to examine the proposed hypotheses using bootstrapping resampling in SmartPLS. The results of the hypotheses testing are provided in Table 4 and Figure 2. The results showed that only three proposed hypotheses were supported and two hypotheses were not supported. The first hypothesis $\left(\mathrm{H}_{1}\right)$ and last hypothesis $\left(\mathrm{H}_{5}\right)$ have failed to be supported as the results showed that cost $(\beta=0.0500)$ and peer influences $(\beta=-0.0590)$ have no significant influence on the students' behavioural intention to select a university. However, the second hypothesis $\left(\mathrm{H}_{2}\right)$, third hypothesis $\left(\mathrm{H}_{3}\right)$ and fourth hypothesis $\left(\mathrm{H}_{4}\right)$ were supported as the infrastructure $(\beta=$ $0.2500)$, placement opportunities $(\beta=0.2830)$ and parental advice $(\beta=0.1650)$ have significant impacts on students' behavioural intention to select a university. Within these three significant factors, placement opportunities has the greatest impact on the students' behavioural intention in university selection, followed by the infrastructure and parental advice.

Table 4: $\quad$ Path-Coefficient Assessment using PLS-SEM

\begin{tabular}{|c|c|c|c|c|c|c|}
\hline Hypothesis & Paths & $\begin{array}{l}\text { Path } \\
\text { Coefficient }\end{array}$ & $\begin{array}{l}\text { Standard } \\
\text { Deviation }\end{array}$ & T-stat & $\begin{array}{l}P \text { - } \\
\text { value }\end{array}$ & Results \\
\hline $\mathrm{H}_{1}$ & $\mathrm{C}->\mathrm{BI}$ & 0.0500 & 0.1140 & 0.4350 & 0.3320 & $\begin{array}{l}\text { Not } \\
\text { Supported }\end{array}$ \\
\hline $\mathrm{H}_{2}$ & $\begin{array}{l}\text { INF } \quad-> \\
\mathrm{BI}\end{array}$ & 0.2500 & 0.1340 & 1.8700 & 0.0310 & Supported \\
\hline $\mathrm{H}_{3}$ & $\begin{array}{ll}\mathrm{PO} & -> \\
\mathrm{Bl} & \end{array}$ & 0.2830 & 0.1180 & 2.4060 & 0.0080 & Supported \\
\hline $\mathrm{H}_{4}$ & $\begin{array}{ll}\mathrm{PA} & -> \\
\mathrm{BI} & \end{array}$ & 0.1650 & 0.0820 & 2.0060 & 0.0220 & Supported \\
\hline $\mathrm{H}_{5}$ & $\mathrm{PI}->\mathrm{BI}$ & -0.0590 & 0.0810 & 0.7190 & 0.2360 & $\begin{array}{l}\text { Not } \\
\text { Supported }\end{array}$ \\
\hline
\end{tabular}




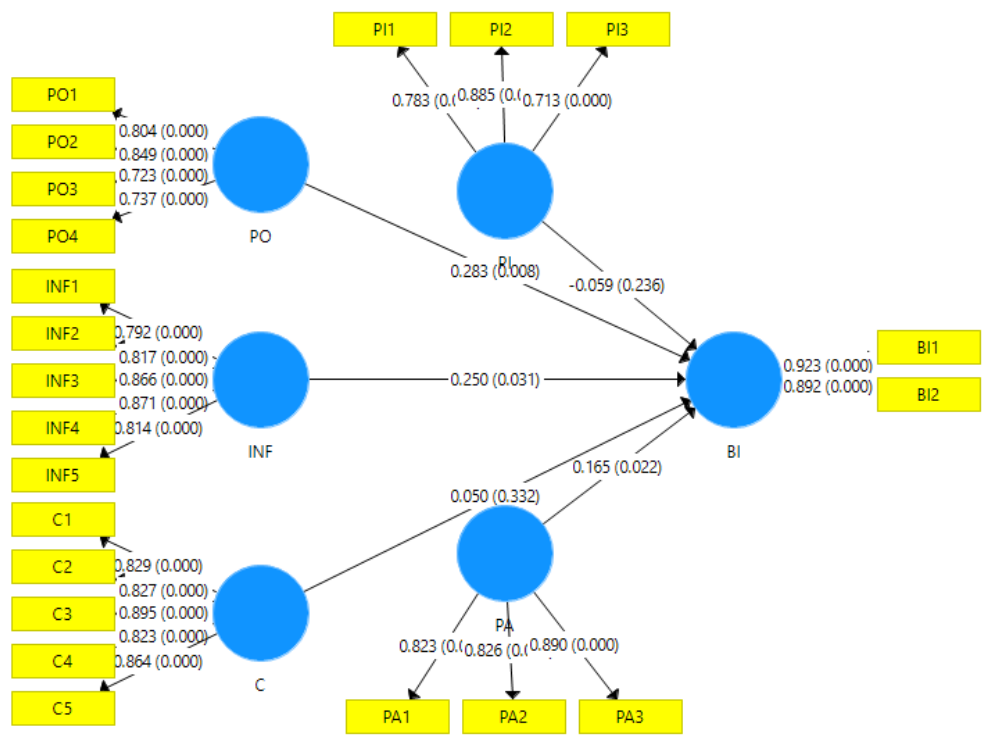

Figure 2: $\quad$ Path-Coefficient Results In PLS-SEM

Lastly, the R-Squared $\left(R^{2}\right)$, predictive relevance $\left(Q^{2}\right)$ and effect size $\left(f^{2}\right)$ of the factors were provided in Table 5. The R-Squared $\left(R^{2}\right)$ was used to assess the coefficient of determination and the value of 0.3800 indicated that 38 per cent of the students' behavioural intention are explained by the five proposed factors. Moreover, the predictive relevance value $\left(Q^{2}\right)$ that is greater than zero $(0.2630)$, showed that the five factors could predict students' behavioural intention in selecting a university. Moreover, the effect size $\left(\mathrm{f}^{2}\right)$ showed that all factors have a small effect size on students' behavioural intention as the effect size value is lower than 0.15 (Cohen, 1988).

Table 5: $\quad$ Determination of Coefficient $\left(R^{2}\right)$, Predictive Relevance $\left(Q^{2}\right)$ and Effect Size $\left(f^{2}\right)$

\begin{tabular}{llll}
\hline Factors & $\mathbf{R}^{\mathbf{2}}$ & $\mathbf{Q}^{\mathbf{2}}$ & $\mathbf{f}^{\mathbf{2}}$ \\
\hline C & & & 0.0020 \\
INF & & & 0.0330 \\
PO & & & 0.0250 \\
PA & & & 0.0040 \\
PI & & & 0.0510 \\
BI & 0.3800 & 0.2630 & \\
\hline
\end{tabular}

\section{Discussions}

This study examined the influences of cost, infrastructure, placement opportunities, parental advice and peer influences on the secondary school students' university selection. As presented in the previous section, three proposed hypotheses were supported (infrastructure, placement opportunities and parental advice) and two hypotheses were rejected (cost and peer influences). Infrastructure was found to have a positive significant influenced on the students' behavioural intention to select a university. This finding supports the earlier studies that concluded with similar results (Mahdzar et al., 2021; JamesMacEachern \& Yun, 2017; Mishra, Yousaf \& Amin, 2021). This shows that the secondary school students are more likely to select a university that is equipped with sufficient infrastructure or facilities such as a library with abundant resources and reading materials, 
high-quality and cosy accommodation, a technology-enabled campus, administrative support, and others. Similar to Songan et al. (2010), James-MacEachern and Yun (2017) and Mishra, Yousaf and Amin (2021), the placement opportunities of the university also have a significant effect on the students' decision in selecting a university. This indicates that secondary school students are not only concerned about their studying life in the university but they are also anxious about their life after completing their studies at the university. The students are more likely to select a university that provides placement opportunities for their students or a university that has a good employment rate for their graduates. Moreover, in selecting their university, students are also influenced by their parents' opinion as it has a positive significant association with the behavioural intention of students in selecting their university. This is in line with the findings by Wong (2019), Alfattal (2017), and Sarkodie, Asare and Asare (2020) who has found that university selection decision is significantly influenced by parents' advice. As most students usually have no idea about the strengths of the universities, therefore, they are likely to seek and follow the opinions of their parents, who are also paying for their studies.

However, the positive insignificant effect of cost or study fees was found in this study. This finding signified that students' university selection decision is not influenced by the cost or study fees of the university and this is contrastive with the findings by Mahdzar et al. (2021) and Nanath, Sajjad and Kaitheri (2021). There are numerous study loans available that could be applied by the students to reduce their financial burdens such as National Higher Education Fund Corporation (PTPTN), Sarawak Foundation and other organizations. Moreover, several universities and organizations also provide scholarships or study grants for eligible students. Besides that, the study fees or cost in public HEls is charged at a lower rate. All of these could be the possible reasons for this finding. Therefore, students are not so worried about the cost or study fees when there are selecting their university. Lastly, unlike Wong (2019) and Mohd Yusuf, Ghazali and Abdullah (2017), the result showed that friends and peers of the students don't influence their decisions in selecting university as peer influence is not significantly affecting the students' behavioural intention. As the respondents of the study are secondary school students, therefore, their friends and peers are those of the same age or likely to have the same information as them. Thus, the students tend to follow the advice from their parents rather than their friends as their parents usually have more information about the university selection, compared to their friends and peers.

\section{Implications}

Numerous factors have been investigated in previous studies that influenced university selection decisions. However, these factors stand alone as no well-established framework could amalgamate with the university selection factors (Mishra, Yousaf \& Amin, 2020). Therefore, this study takes initiative to categorise these factors into two main predictors as suggested in TRA to better understand the influence of these factors on students' behavioural intention in selecting a university. As found in this study, infrastructure and placement opportunities that could affect students' attitudes have a significant influence on their behavioural intention in university selection. Besides that, for the subjective norms, parental advice is found to have a significant association with students' behavioural intention in selecting a university. Therefore, this study contributes from the theoretical perspective by proving that those university selection factors could be categorised into attitude and subjective norms as suggested by the well-developed behavioural model, TRA. Although the 
direct relationship of those selection factors toward the two predictors of the model is not examined in this study, it could provide a brief idea about the application of the TRA in determining students' behavioural intention in their university selection decision.

This study also provides several managerial implications for the relevant stakeholders such as policymakers, HEls, education counsellors and the like. The significant determinant factors that influenced secondary school students' behavioural intention in selecting their university were identified in this study. Therefore, the HEls and their marketing teams should utilize this finding beneficially as they would understand the factors that could be influencing students' decisions. For example, infrastructure, placement opportunities and parental advice are significant factors that affect students' behavioural intentions. The HEls and their marketing teams, therefore, should focus on these three significant factors in improving the enrolment of students. For instance, the universities should ensure their universities have sufficient infrastructure and facilities as this is the main consideration of the students when there are selecting a university. The marketing teams of those universities should also focus on promoting their universities by introducing or highlighting the infrastructure and facilities of the university as this could be the main selling point to attract students' interest. Besides that, the universities also have to establish good connections and relationships with their industrial partners including providing the internship opportunities for their students to join the organizations as this could increase the marketability and also the employment rate of the students upon their graduation. In addition, the universities should also provide counselling services for their students in assisting them to choose better career paths after their study. The employment rates of the graduates could also be used as one of the selling points in their marketing strategy as potential students are most concerned about this. Furthermore, the marketing events to promote the universities should target the parents rather than students themselves as the students are likely to seek advice from their parents when they are selecting a university. Since these factors have significant influences on students' behavioural intention in selecting their university, therefore, the stakeholders should concentrate on improving the quality, standard and attractiveness of these three factors as they are crucial to increase the enrolment of the students.

\section{Conclusions, Limitations and Suggestions}

In this study, the determinant factors that influenced the behavioural intention of the secondary school students in selecting a university are examined. Based on TRA, the five factors proposed in this study, namely cost, infrastructure, placement opportunities, parental advice and peer influences were categorized into two main predictors of behavioural intention, namely attitudes and subjective norms. From the responses collected from 133 Form Four and Form Five students in Sarawak, the study revealed that cost and peer influences have no significant influence on students' behavioural intention in selecting their university. However, infrastructure, placement opportunities, and parental advice have significantly affected the behavioural intention of the students' university selection. This finding provided an important implication for the relevant stakeholders. For instance, the HEIs require such information in designing the marketing strategy to attract the interest of the secondary school students and thus increase their enrolment. This is especially so for private HEls as the number of enrolment is their main source of revenues.

This study has some limitations. For example, the direct relationship of the university selection factors towards the two predictors in TRA were not examined in this study. 
Therefore, it could provide a more robust finding if the future study could investigate this direct relationship, rather than categorising these factors into these two predictors of students' behavioural intention. Besides that, the sample size of the study only consists of 133 secondary school students from Sarawak. Future studies are advised to increase the number of respondents to provide a more solid finding. Moreover, the composition of the respondents is also not equally distributed as most of the students are dominated by females and also Chinese. Future study is encouraged to balance the respondents' composition as it may destruct the reliability of the findings. Furthermore, as the majority of the participated students are coming from four divisions, therefore future studies could consider the use of geographical sampling to gather the responses from all divisions in Sarawak, including those from the rural schools. Lastly, the future study can also consider investigating the perspective of the different groups of respondents such as STEM versus Art and Humanities students, students from rural areas versus urban areas, etc. This is because a different group of respondents may have different opinions on the subject matter.

\section{References}

Agrey, L., \& Lampadan, N. (2014). Determinant Factors Contributing to Student Choice in Selecting a University. Journal of Education and Human Development, 3(2): 391-404.

Ahmad, S. Z., Buchanan, F. R., \& Ahmad, N. (2016). Examination of students' selection criteria for international education. International Journal of Educational Management, 30(6): 1088-1103.

Alfattal, E. (2017). International students' college choice is different. International Journal of Educational Management, 31(7): 930-943.

Awadallah, E., \& Elgharbawy, A. (2020). Utilizing the theory of reasoned action in understanding students' choice in selecting accounting as major. Accounting Education, 30(1): 86-106.

Byrne, B. M. (2013). Structural equation modelling with AMOS: basic concepts, applications and programming. Routledge, New York.

Cohen, J. (1988). Statistical Power Analysis for the Behavioral Sciences. $2^{\text {nd }}$ Edition. New York, NY: Routledge Academic.

Fishbein, M., \& Ajzen, 1. (1975). Belief, attitude, intention, and behaviour. Reading, M.A: Addison-Wesley.

Gefen, D., Straub, D., \& Boudreau, M. C. (2000). Structural Equation Modeling and Regression: Guidelines for Research Practice. Communications of the Association for Information Systems, 4: 1-70.

Gold, A. H., Malhotra, A., \& Segars, A. H. (2001). Knowledge management: An organizational capabilities perspective. Journal of Management Information Systems, 18(1): 185-214.

Hair, J. F., Hult, G. T. M., Ringle, C. M., \& Sarstedt, M. (2017). A primer on partial least squares structural equation modelling (PLS-SEM). $2^{\text {nd }}$ Edition. Thousand Oaks, CA: Sage.

Haron, H., Abdul Hamid, N. A., Jamaludin, J., \& Ku Azan, K. N. (2017). Students' Decision Factors in Choosing Private Higher Education Institutions. International Journal of Academic Research in Business and Social Sciences, 7(11): 1372-1382.

$\mathrm{Hu}, \mathrm{L}-\mathrm{T}$., Benlter, P. M. (1999). Cutoff criteria for fit indexes in covariance structure analysis: Conventional criteria versus new alternatives. Structural Equation Modeling: $A$ Multidisciplinary Journal, 6(1): 1-55. 
James-MacEachern, M., \& Yun, D. (2017). Exploring factors influencing international students' decision to choose a higher education institution: A comparison between Chinese and other students. International Journal of Educational Management, 31(3): 343-363.

Kline, R. B. (2011). Principles and Practice of Structural Equation Modeling. $2^{\text {nd }}$ Edition, Guilford Press, New York.

Mahdzar, M., Omar, M. K., Jaapar, A., Zaini, W. Z. W. M. (2021). Factors Influencing Orang Asli Students' Intention to Study at A Higher Educational Institution in Malaysia. International Journal of Academic Research in Progressive Education \& Development, 10(2): 233-244.

Mishra, A., Yousaf, A., \& Amin. (2021). An attribute-based framework for students' motivation to join an HEl: a self-determination theory perspective. International Journal of Educational Management, 35(1): 201-215.

Mitic, S., \& Mojic, D. (2020). Student choice of higher education institutions in a posttransitional country: evidence from Serbia. Economic Research-Ekonosmka Istrazivanja, 33(1): 3529-3527.

Yusuf, M. B. N., Ghazali, M. Q. M., Abdullah, M. F. S. (2017). Factors Influencing Local and International Students Decision in Choosing Public Higher Learning Institutions in Northern Region of Malaysia. International Journal of Social Sciences, 48(1): 29-41.

Nanath, K., Sajjad, A., \& Kaitheri, S. (2021). Decision-making system for higher education university selection: comparison of priorities pre- and post COVID-19. Journal of Applied Research in Higher Education, Vol. ahead-of-print No. ahead-of-print. doi: 10.1108/JARHE-08-2020-0277

Ramalu, J. C. D., Abu Bakar, N., \& Nijar, N. N. (2013). Factors that Determine Students' Preferences in Selecting Higher Learning Institution. Infrastructure University Kuala Lumpur Research Journal, 1(1): 27-38.

Roscoe, J. T. (1975). Fundamental research statistics for the behavioural sciences. Second Edition. New York: Holt Rinehart and Winston.

Sarkodie, N. A., Asare, A., \& Asare, D. (2020). Factors Influencing Students' Choice of Tertiary Education. Africa Development and Resources Research Institute (ADRRI) Journal, 28(11(5)): 58-92.

Shah, M., Kansal, M., \& Chugh, R. (2021). Why do Mongolian students choose to study in Australia? International Journal of Comparative Education and Development, 23(1): 113.

Sim, A. K. S., Tan, K-L., Sia, J. K-M., \& Hii, I. S. H. (2021). Students' choice of international branch campus in Malaysia: a gender comparative study. International Journal of Educational Management, 35(1): 87-107.

Songan, P., Sam, H. K., Tonga, G., Abdul Rahman, M., \& Wah, T. K. (2010). Factors Influencing Student Choice: A study of a Malaysian Public University. Asian Journal of University Education, 6(1): 75-89.

Wagner, K., \& Fard, Y. 2009. Factors Influencing Malaysian Students' Intention to Study at a Higher Educational Institution. Accessed at https://www.gcasa.com/PDF/malaysia/Wagner-Fard.pdf [17 August 2021].

Wong, W. P. M. (2019). Destination Choice of Higher Education among the Local Secondary School Students in Sarawak. Borneo Journal of Social Science and Humanities, 1(1): 117. 
INTERNATIONAL JOURNAL OF ACADEMIC RESEARCH IN PROGRESSIVE EDUCATION AND DEVELOPMENT

Vol. 10, No. 3, 2021, E-ISSN: 2226-6348 @ 2021 HRMARS

Yamamoto, G. T. (2006). University evaluation-selection: a Turkish case. International Journal of Educational Management, 20(7): 559-569. 